\title{
VAN GÖLÜ'NDE VAPUR IŞLETME TEŞEBBÜSLERI (1879-1907)
}

\section{FAHRETTIN TIZLAK}

\section{Giriş: Türklerde Denizcilik Kültürü:}

Türkler Anadolu'ya ilk adım attukları anlardan itibaren denizlerle ve denizcilik ile ilgilenmeye başlamışlardır. Bu ilginin kökenlerinin daha önceki dönemlere dayandığı bilinmektedir. Mesela bazı Türk hükümdarlarının çocuklarının isimleri Tengiz yani Deniz idi' ${ }^{1}$ Aynı şekilde Hazar Denizi ile Baykal Gölü'nde de Türklerin Anadolu'ya gelmeden önce denizcilik ile uğraştıkları bilinmektedir. Nitekim Timur, Yıldırım Bayezit'ı esir aldığı zaman O'na, "...sizin ceddiniz gemicidir..." diye hitap ederek, ${ }^{2}$ bu gerçeğin tarihi temellerinin derin olduğunu ifade etmiștir.

Türklerin Anadolu'ya gelmeleri ile bu faaliyet daha da geliştirilerek devam ettirilmiş ve ilk Türk denizcisi olarak bilinen Caka Bey, Akdeniz sahillerinde İzmir Beyliği'ni kurarak karada olduğu gibi denizde de gücünü göstermiştir ${ }^{3}$. Diğer yandan, Süleyman Şah'ın yerine bıraktığı Ebu'1- Kasım da Bizans'tan Gemlik Koyu'nu alarak burada tarihte yeri ve önemi büyük olan ilk Türk tersanesini tesis etmiştir'. Bu gelişmeler Alaaddin Keykubat tarafından Alaiye'nin fethi ile daha da büyük bir merhaleye ulaştırılır ki, bu, Türk denizciliği için büyük bir adımdır ${ }^{5}$.

Osmanlılar zamanında da ilk etapta Marmara Denizi'nde ve daha sonra Çanakkale Boğazı'nda denizcilik faaliyetlerine başlanır. Bu faaliyetlerde Aydınoğulları zamanında özellikle Umur Bey tarafından geliştirilen denizcilik geleneğinin katkısı büyük olmuşturi. Osmanlı Devleti'nin bu tarihî temel-

1 Ali İhsan Gencer,Bahriye'de Yapılan Islahat Hareketleri ve Bahriye Nezareti'nin Kuruluşu (1789-1867), İstanbul, 1985, s. 1.

${ }^{2}$ A.I. Gencer, a.g.e., s. 1.

${ }^{3}$ Mücteba İlgürel, "Buharlı Gemi Teknolojisini Osmanlı Devleti'nde Kurma Teşebbüsleri", Çağını Yakalayan Osmanlı, Yay. Haz. Ekmeleddin İhsanoğlu-Mustafa Kaçar, İstanbul, 1985, s. 143.

\footnotetext{
'A.I. Gencer, a.g.e., s. 2

${ }^{5} \mathrm{M}$. İlgürel, a.g.m., s. 143.

${ }^{6} \mathrm{M}$. İlgürel, a.g.m., s. 143-144.
} 
lere dayanarak geliştirdiği denizcilik faaliyetlerinin, kuruluşu takip eden dönemlerde hızla ilerlemiş olduğunu biliyoruz. Nitekim, Osmanlı Devleti'nin daha Fatih döneminde denizcilik alanında akın faaliyetlerinden çıkarak deniz aşırı seferlere girişmeye başladığı bilinmektedi ${ }^{7}$. Bu çerçevede fetihten sonra yeni tersaneler yapılarak ve yeni gemi yapım teknikleri geliştirilerek Osmanlı donanması Akdeniz'e açılabilecek seviyeye ulaşturılmıştır ${ }^{8}$. Bunda Fatih, II. Bayezıt ve Yavuz dönemlerinde ülkenin istikbalinin denizlerde aranmaya başlamasının ve bu doğrultuda bahriye meselesinin öneminin kavranmasının etkisi vardır".

Diğer yandan, bu dönemde denizcilikteki satvetin kaynağı veya göstergesi olarak bir yandan deniz üsleri ve tersaneler kurulması faaliyetlerine önem verilirken, bir yandan da nehir ve göller üzerinde gemi inşa tezgahları ile nehir filolarının kurulmasına gereken önemin verilmiş olduğunu görüyoruz. Öyle ki, XVI. ve XVII. yüzyıllarda dönemin en büyük nehir filoları meydana getirilmiştir. Nitekim, 1534'te Bağdat'ın zabundan sonra Basra Körfezi'ne inen Kanunî'nin orduları bu iște Dicle ve Frat nehirlerinin nakliyat imkanlarından istifade etmiştir. Bu hususta Birecik önemli bir merkez konumunda idi ki, burada nehir gemilerinin inşa faaliyetlerinin yürütülmüş olduğunu ve burasının bu yönüyle bölgede önemli bir merkez durumunda bulunduğunu biliyoruz ${ }^{10}$. Öyle ki, 1565 yılında Şat bölgesinde yer alan bir taifenin girişmiş olduğu isyan hareketinin basturılmasında Birecik'ten 500 ve Bağdat'tan 200 gemi ile 10000 'den fazla askerin Basra'ya gönderilmiş olduğu bilinmektedir"l.

Bu dönemlerde Fırat ve Dicle nehirlerindeki nakliyat sadece askerî boyutlu değildi. Bu nehirlerde o zamanlardan itibaren zahire ve ticarî eşya nakliyaunın da yapılmaya bașlanmış olduğunu biliyoruz ${ }^{12}$. Yine, XVI. yüzyıl sonlarında Belgrad ve Budapeşte arasındaki nehir ticaretinin yüzde doksanı da Türk gemileri ve tüccarları vasıtası ile yürütülmüștür ${ }^{13}$.

${ }^{7}$ A.I. Gencer, a.g.e., s. 8.

${ }^{8} \mathrm{M}$. İlgürel, a.g m., s. 144.

9.i. Gencer, "İstanbul Tersanesinde Açılan IIlk Tıp Mektebi", I.Ü. Tarih Dergisi, s. 31. İstanbul, 1978, s. 301.

16) D. Bediz, a.g.m., s. 6.

"D. Bediz, a.g.m., s. 7.

12 Cengiz Orhoulu, Osmanlı Imparatorluğu'nda Şehircilik ve Ulaşım Üzerine Araşurmalar, Derleyen: Salih Özbaran, İzmir 1984, s. 117. Üstelik bu su yolunu Türklerden bașka Hintli ve Atrupalı tacirler de kullanmakta idi.

${ }^{13}$ D. Bediz, a.g.m., s. 7. 
Aynı șekilde 1521'de Belgrad'ın zaptı ile Tuna ve buna bağlı nehirler üzerinde faaliyet gösterecek filoların inşası işlemlerine başlanmıştur. Nitekim, aynı dönemde Tuna ve kollarında sayıları zaman zaman 500'ü aşan çeşitli cinsten gemiler sefer yapmakta idi" ${ }^{1}$.

Bizim konumuzu oluşturan Van Gölü'nün de bu dönemlerde yürütülen denizcilik faaliyetlerinden nasibini almış olduğunu ve bu bağlamda Tatvan'da Mimar Sinan'a inşa ettirilen gemilerle bu gölün gemi seferlerine açılmış olduğu bilinmektedir ki, burada ilk etapta başlatulan faaliyetler daha çok ordunun ikmal hizmetlerinin yürütülmesi amacına yönelikti ${ }^{15}$.

Yukarıda vermiş olduğumuz örnekler de bize göstermektedir ki, özellikle XVI. yüzyılda Türk denizciliği, gerek askerî ve gerekse sivil açılardan oldukça ileri düzeydedir ve bu iş sadece denizlerde değil, nehir ve göllerde de oldukça önemli boyutlarda icra edilmektedir. Dolayssıyla Osmanlı, daha klasik çağlarından itibaren nehir ve göl gemiciliğine yabancı değildir. Nitekim, Fırat ve Tuna gibi büyük nehirlerde devletin tesis etmiş olduğu ve adına İnce Donanma denilen nehir donanmaları ile nehir ulaşımının sağlanmış olduğu bilinmektedir ${ }^{16}$.

Ancak, XVI. yüzyılda Osmanlının denizcilik alanında sahip olduğu güce rağmen, Avrupa'da bu alanda meydana gelen değişmeler, diğer alanlarda olduğu gibi burada da zamanında izlenememiștir. Çünkü, Fransız, İngiliz ve Hollandahılar bu dönemlerde ticaretin önemini kavrayarak denizciliği geliştirmişler ve sanayi inkılâbı ile buhar gücünü gemilere tatbik ederek gemicilikte büyük atılımlara imzalarını atmışlardır.

\section{A- Osmanlı Devleti'nde Denizcilik Alanında Yenilik Cabalan:}

Osmanlı Devleti'nde ise her alanda yapılan yeniliklerin başarısızlıkla sonuçlanması bir yana, XVIII. yüzyılın sonlarında yaşanan Çeşme faciası devleti donanmasız bırakmıștır. Bu, İnebaht yenilgisinden sonra Osmanlı denizciliğine vurulan ikinci büyük darbedir. Fakat bu olay, Osmanlı devlet adamlarının denizciliği daha çok düşünmesine sebep olur ${ }^{17}$. Nitekim bunun tabii bir neticesi olarak 1773'de III. Mustafa tarafından Baron de Tot'a Haliç'te bah-

${ }^{14}$ D. Bediz, a.g.m., s. 6-7.

${ }^{15}$ D. Bediz, a.g.m., s. 6.

${ }^{11 \mathrm{C}}$ C. Orhonlu, a.g.e., s. 83.

${ }^{17}$ A.İ. Gencer, "Özel Bahriye Mektebi Hakkunda Bir Genelge (1851)", I.U. Tarih Enstitüsü Dergisi, s. 7-8, İstanbul, 1977, s. 413. 
riye mühendisliğine yönelik olarak bir okul kurdurtulur. Ardından III. Selim'in de denizcilik meselesi ile ciddi olarak ilgilenmiș olduğunu görüyoruz. Bu ilginin neticesinde önemli bir deniz gücü meydana getirilir ki, bu deniz gücü Fransız ve İngiliz donanmalanı ile yarışabilecek düzeydedir. III. Selim ayrıca, 1805 yılında yayınlamış olduğu bahriye kanunnamesi ile Kasımpaşa Tersanesi'nde yapılacak olan bir dizi ıslahatı başlatır ${ }^{18}$. Fakat Kabakçı olayı ile O'nun bu alanda yapmak istediği faaliyetler de sekteye uğrar.

II. Mahmut'un da Osmanlı denizciliği ile ilgili konulara yabancı kalmadığını ve 1827 yılında Osmanlı ülkesine buharlı gemi teknolojisini sokmuș olduğunu biliyoruz ${ }^{19}$. Halkın ilk defa gördüğü ve adına Buğu Gemisi dediği $i^{20}$ bu gemiden sonra Osmanlı ülkesinde, artuk denizcilik alanında Avrupada olduğu gibi buhar gücü ile çalışan vapurlar kullanılmaya başlanacaktır.

Tanzimat dönemine gelindiğinde de Osmanlı denizciliğinin ıslahına ve geliştirilmesine yönelik faaliyetlere devam edilmiş olduğunu görüyoruz. Bunun için ilk etapta bir takım idari düzenlemelerin yapılmış olduğu bilinmektedir. Ardından ise Osmanlının denizciliği geliștirmeye yönelik bir takım gayretler sarfetmiş olduğunu biliyoruz. Yani Tanzimat, "...mülk ve millete ifade eylediği hubb-ı medeniyeti ticaret-i bahriyemizde de sürat ve suhulet..."le göstermek istedi..."21. Çünkü, XIX. yüzyıl, dünya genelinde büyük denizlerde ve karalarda nakliyatun ilerlediği bir dönemdir ${ }^{22}$. Böyle olunca da Osmanlının bu sürecin dışında kalması beklenemezdi. Bu nedenle XIX. yüzyılda Avrupa ülkelerinin denizcilik alanındaki gelişmişliği karşısında Osmanlı denizciliğinin de geliştirilebilmesi için çeşitli çarelere baş vurulmuştur. Bu çarelerden en belirgini, bu alanda şirketlerin tesis edilmesi uygulamasına geçilmesidir ${ }^{23}$.

${ }^{18}$ A.I. Gencer, Ist. Tersanesinde IIk Tip Mekt..., s. 302.

${ }^{19}$ Abdülahad Nuri, Seyr-i Sefain Ídaresinin Tarihçesi, İstanbul, 1926, s. 13-14: A.I. Gencer. a.g.e., s. 109; Ercüment Kuran, "XIX. Yüzyılda Osmanlı Derleti'nde Deniz Ulaşımı- İdare-i Mahsusa'nın Kuruluşu ve Faaliyeti", Çağını Yakalayan Osmanlı, Yay. Haz; Ekmeleddin İhsanoğlu-Mustafa Kaçar, İstanbul, 1995, s. 159.

${ }^{20}$ A.I. Gencer, a.g.e., s. 109.

${ }^{21}$ A. Nuri, a.g.e., s. 13.

${ }^{22}$ Yusuf Kemal Tengirşek, "Tanzimat Devrinde Osmanlı Devleti'nin Harici Ticaret Siyaseti", Tanzimat $I$, İstanbul, 1940, s. 298.

${ }^{23}$ M. İlgürel, a.g.m., s. 156; Rifat Önsoy. Tanzimat Dōnemi Osmanlı Sanayii ve Sanayileşme Politikası, İş Bankası Yayınları,(tarihsiz), s. 126. 


\section{B- Osmanlı Devleti'nde Sivil Taşımacılık Alanında Gelişmeler:}

Bahsettiğimiz politikaların gereği olarak Osmanlı Devleti'nde bu sefer sivil taşımacılığa yönelik olarak teşebbüslerin başlatılmış olduğunu görüyoruz. Aslında bu faaliyetlerin temelinin de 1830'lu yıllarda Osmanlı tebası olan kişilerin yine Osmanlı sularında sivil olarak gemi işletmeye başlamalarına dayandığını söyleyebiliriz. Bir başka deyimle, Osmanlı sahillerine ve Boğaziçine yabancı gemilerin 1830'lardan itibaren yolcu getirip götürmeye başlamaları, yerli müteşebbislerin bu alanda harekete geçmelerine sebep olacaktır. Yani, Osmanlı ülkesinde bu alanda yerli teşebbüslerin başlatılmasına yabancılar ön ayak olmuşlardır ${ }^{24}$. Bu faaliyetlerden etkilenen devlet, meseleye ancak 1840 'lı yıllarda el atacaktur. Nitekim bu işlerle meşgul olmak üzere bahriye idaresine bağlı olarak müstakil bir idare mekanizması oluşturulması düşünülür. Bu düșüncenin eseri olmak üzere Fevaid-i Osmâniye adıyla bir kuruluş ortaya çıkarılır ki, bu kuruluș, Osmanlı Devletinde denizcilik alanında yolcu ve eşya taşımacılık faaliyetlerinin temelini teşkil edecek$\operatorname{tir}^{25}$. Böylece bu kuruluşun da katkılanı ile o zamana kadar genellikle yelkenliler vasıtası ile yapılan deniz ticaretinde buhar gücü ile çalışan vapurlar da kullanılmaya başlanarak, Osmanlı deniz ticaretinin hem genişletilmesi hem de süratlendirilmesi sağlanmış oluyordu. Bu çerçevede mesela 1844 yılında Tersane, Eser-i Hayr ve Seyr-i Bahri adıyla sahip olduğu iki buharlı gemi vasıtası ile bizzat kendisi boğazda eşya ve yolcu taşımacılığına başlayacaktur. Aynı yıl Marmara denizinde faaliyet göstermek üzere bir başka gemi daha satın alınarak taşımacılık işi genişletilir. 1851 yılına geldiğimizde ise, Boğaziçi'nde insan ve yük taşımak maksatlarına yönelik olarak Fuat ve Cevdet paşaların gayretleri ile Şirket-i Hayriye kurulur ${ }^{26}$. 1855'te de Mecidiye Kumpanyası kurulur $^{27}$. Bundan bir müddet sonra Mithat Paşa'nın Bağdat valiliği sırasında bir vapur şirketi tesis ettiğini ve kendisinden önceki vali Namık Paşa'nın

${ }^{24}$ A. Nuri, a g.e., s. 14. Ki, aym dönemlerde İngilizlerin Fırat ve Dicle Nehirleri üzerinde buharlı gemi işletme teşebbüslerinin varlığın da unutmamak gerekir. Bu konuda bkz; Fahrettin Tızlak, "İngiltere'nin Fırat Nehri'nde Vapur İşletme Girișimi Hakkında Yeni Bilgiler(18341836)", Ondokuz Mayıs Üniversitesi Eğitim Fakültesi Dergisi, S. 6, Samsun, 1991, s. 293-301. Ayrıca 1861'den itibaren onlar bu işi kurmuş oldukları Fırat ve Dicle Buharlı Gemi Nakliyat Şirketi ile yapacaklardır.

25 A. Nuri, Türkiye Seyr-i Sefain Idaresi Rehberi, Matbaa-i Ihsan, 1926. s. 9; E. Kuran. a.g.m., s. 160 .

${ }^{20}$ A. Nuri, a.g.e., s. 15; E. Kuran, a.g.m. s. 160; Mübahat Kütükoğlu, "Osmanlı Buharlı Gemi İşletmeleri ve İzmir Kōrfezi Hamidiye Şirketi", Cağım Yakalayan Osmanlı. Yay. Haz; Ekmeleddin İhsanoğlu- Mustafa Kaçar, İstanbul, 1995, s. 175.

${ }^{27}$ E. Kuran, a.g.m., s. 163. 
Dicle'de taşımacılık için İngiltere'den getirtmiş olduğu gemileri işletmeye koymuş olduğunu biliyoruz. İdare-i Nehriye ve Asır isimli küçük teknelerden başka Mithat Paşa'nın ayrıca, İdare-i Ummanî-yi Osmanî adıyla kurmuş olduğu bir şirket vasıtası ile Ninova, Necid ve Babil isimli vapurlar ile Basra Süveyş- İstanbul seferlerine başlamış olduğunu da biliyoruz ${ }^{28}$.

Böylece, 1840'lı yıllardan itibaren devreye resmi kuruluşların da girmesi ile Osmanlı sularında yabancı bandıralı gemilerin yanında, Osmanlı bandırası taşıyan gemilerin yan yana resmî ve sivil hüviyetli olarak birlikte faaliyet yürüttükleri görülmeye başlanır. Bu sürecin bir sonucu olarak Karadeniz, Marmara, Ege ve Akdeniz'de bulunan çeșitli limanlar arası hatlarda seferlere başlanır ${ }^{29}$. Ancak, hemen belirtelim ki, devlet tarafindan yürütülen bu seferler genelde büyük ölçüde Tersane-i Âmireye bağlı şirketler vasıtası ile gerçekleştirilmiştir ${ }^{30}$.

Bu arada II. Abdülhamit zamanına gelindiğinde Türk deniz ticaret filosunun daha da geliştirilmesi için biıtakım faaliyetlerin yürütülmeye devam edildiğini görüyoruz. Mesela 1881'de İzmir Körfezi Osmanlı Vapurları Şirketi kurularak Sakız, Çeşme, Kuşadası vs. yerlere seferler yapılmaya başlanir ${ }^{31}$.

Fakat, nehir, göl ve liman içi taşımacılık işlerinde durumun biraz daha değişik olduğunu ğörüyoruz. Şöyle ki; yukarıda da değinildiği üzere XIX. yüzyıl, Avrupa ülkelerinin denizcilik alanındaki gelişmişliği karşısında Osmanlı denizciliğinin de geliştirilebilmesi için çeşitli çarelere baş vurulduğu

${ }^{28}$ E. Kuran, a.g.m., s. 163. Ama, O'nun bu faaliyetleri kendisinin valilikten ayrılması ve ardından da Íngiliz rekabetinin de etkisi ile daimi olamaz. Bu konuda bkz., ayı yer.

${ }^{29}$ M. Kütükoğlu, a.g.m., s. 166-172.

${ }^{30}$ M. Kütükoğlu, a.g.m., s. 173.

${ }^{31}$ E. Kuran, a.g.m., s. 162. Sonraki tarihlerde de bazı şirketlerin faaliyete geçtiklerini görürüz, mesela 1894 yılmda Gümüşciyân, 1905 yılmda Pandelli Biraderler, 1906 yılında Hayriye-i Hamidiye Şirketleri faaliyete geçer. Diğer yandan, 1910 yılında Hilal Osmanlı Anonim Vapur Şirketi Istanbul'dan Karadeniz ve Akdeniz limanlarına seferler yapmaya başlar. Meşrutiyetin ikinci defa ilamma kadar bu ünvanmı muhafaza eden şirketin 80 kadar gemi işlettiği bilinmektedir.(Bkz., E. Kuran, a.g.m., s. 161-162). Fakat tam bu sıralarda İdare-i Mahsusanm imtiyaz hakk 75 seneliğine İngilizlere verilmiş, bōyle olunca da şirketin ismi Osmanlı Seyr-i Sefain Şirketi olarak deg̃iştirilmiştir. Ancak ilgililer, bu maksatla basturmıs oldukları hisse senetlerini satamadıklarından dolayı işe başlayamamışlardır. Bunun üzerine verilen imtiyaz fesh edilir. Bunun ardından 1910 yılında Osmanlı Seyr-i Sefain İdaresi kurulur.(Bkz., A. Nuri, Seyr. Sefer Rehberi, s. 9-10). Ancak, belirtilen tarihte idarenin elindeki gemi sayısımın, o yıllarda yabancı şirketlerin sürdürdüğü amansız rekabet yüzünden $18^{\prime} \mathrm{e}$ düșmüş olduğunu gòrüyoruz. Bkz., a.g.m., s. 161. 
ve bu çerçevede bu alanda şirketlerin tesis edilmesi uygulamasma geçildiği bir dönemdir. Bunun tabii bir sonucu olarak denizcilik alanındaki gelişimi sağlayabilmek için bu sahada artık şirketlere de yer verilmeye başlandığına yukarıda değinilmişti. Bu işte tersane gemilerinin yanında, kısmen özel teşebbüse ait gemilerin faaliyete geçmeye başladığı görülmektedir ki, burada özel teşebbüse ait başvuruların incelenmesinden sonra Osmanlı bayrağı taşımak şartı ile en uygun şirkete imtiyaz verilmesi yolu izlenmiştii ${ }^{32}$.

Yine bu sürecin bir gereği olarak ülkenin değişik yerlerinde birtakım faaliyetlerin başlatılmış olduğunu görüyoruz. Mesela, 1863 yılında İznik Gölü'nde vapur işletilmesi için bir teşebbüsün yapılmış olduğu ve yine aymı yıllarda İşkodra Gölü'nde de bir sürat vapurunun çalışturılmış olduğunu biliyoruz $^{33}$. Aynı șekilde, 1864 'lerden itibaren İstanbul ve diğer Osmanlı limanlarında Avusturya, Fransız, İngiliz, Yunan, Rus ve Mısır şirketlerinin sefer yapmakta oldukların biliyoruz. Öyle ki, Karadeniz limanlarında o yillarda hiçbir Türk gemisi işlemez iken, İstanbul-Trabzon arasında İngiliz gemileri işlemekteydi ${ }^{34}$. Bunlardan başka, Mithat Paşa'nın Tuna valiliği sırasında Tuna Nehri'nde Türk ticaret vapurları işletmiş olduğunu da biliyoruz ${ }^{35} .1877$ yılına gelindiğinde ise Yaver Şakir Paşa'nın Mihaliç Nehri ile Apolyon ve Manyas göllerinde başarısız bir vapur işletme girişiminin vaki olduğu bilinmektedir ${ }^{36}$.

\section{C- Van Gölünde Vapur İşletme Faaliyetleri;}

\section{1. Özel Teşebbüsün Faaliyetleri:}

\section{a- Abraham Kafafyan ve Artin Sarrafyan'ın Vapur İşletme İmtiyazı Almalan:}

Yukarıda bahsedilen süreç çerçevesinde Anadolu'nun en büyük gölü olan Van Gölü'nde de vapur işletme teşebbüslerinin başlatılmış olduğunu biliyoruz. Nitekim 1879 yılımın ilk aylarında başlauldığını düşündüğümüz girişimlerin neticesinde 16 Ağustos 1879 tarihi itibariyle Osmanlı tebasından Abraham Kafafyan ve Artin Sarrafyan'a bu konuda imtiyaz fermanı verilmiş-

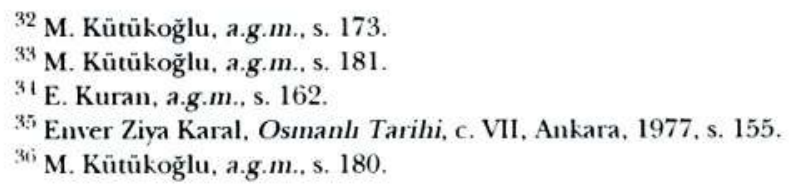


tir ${ }^{37}$. Bu fermana göre ilgililer, Van Gölü'nde vapurla yolcu ve eşya taşımak ile eşya yüklü mavnaları çekmek için bir şirket teşkil amacı ile kendilerine kırk yıllık bir süre için imtiyaz verilmesi isteği ile devlete başvururlar. Başvuru, Şura-ı Devlet Nafia Dairesine incelettirilir ve uygun görülür. Bu çerçevede 13 Ekim 1879 tarihli yirmişer maddelik bir mukavele ve şartname hazırlanır $^{38}$ (Bkz., ek 1, 2).

Bu mukavelenameye göre adı geçen kişiler, imtiyaz fermanının kendilerine tevdi edileceği güne kadar kefalet akçesi olarak Bank-1 Osmanî'ye 500 Osmanlı altını yatırmayı kabul ederler. Yine bu mukaveleye göre söz konusu kişiler, belirtilen miktarı en geç fermanın kendilerine tesliminden bir ay sonrasına kadar yatırmayı taahhüt ederler. Eğer kefalet akçesi yatırıldığı halde ferman hazırlanarak ilgililere teslim edilmez ise imtiyaz fesh edilmiş olacaktır. Kefalet akçesi, adı geçen kişilerin, mukavelede belirtilen süre içerisinde gölde vapurları çalıştırmaya başladıkları andan itibaren kendilerine geri verilecektir(madde 2). Mukaveleye göre imtiyazı alan kişiler, gölde vapur işletilmek üzere yeri ve sayısı devlet tarafından belirlenecek olan noktalara iskeleler ve eşya ambarları inşa etmeyi de taahhüt ederler(madde 3). Bu taahhütte imtiyaz fermanının ilgililere verildiği tarihten itibaren iki sene içerisinde gölün sahillerinde en az dört noktada iskele inşaatuna başlanacağına dair garanti vardır. Aynı şekilde bundan altı ay sonrasına kadar, yani, imtiyaz fermanının verildiği tarihten itibaren iki buçuk senenin bitimine kadar iskelelerin inşası tam. mlanmış olacaktur ve gölde yolcu ve eşya taşımak için en az iki tane vapur işletmeye sokulmuş olacaktur(madde 4). İmtiyaz fermanın verilişinden beş sene sonra ise, eğer ihtiyaç zuhur eder ise, Nafia Nezareti, imtiyaz sahiplerini gölün başka yerlerinde yeni iskeleler inşa etmeye ve buralarda çalışacak yeni vapurları sefere koydurmaya yetkili olacaktur. Öyle ki, bu konuda Nafia Nezareti'nin verecek olduğu emir en geç bir yıl içerisinde yerine getirilerek yolcu taşınmasına başlanacaktır(madde 5). Bu konuda lazım olacak olan arsalar, özel mülkiyete ait ise, imtiyaz sahipleri tarafından satın alınacaktır, yok eğer miri arsası söz konusu olursa bu arsalar devlet tarafindan ilgililere meccanen verilecektir(madde 6).

${ }^{37}$ Başbakanlık Osmanlı Arşivi(BOA), Yıldız Arşivi Sadaret Resmi Maruzau(Y.A. Res.). Dosya 12, Sira 40; BOA, Imtiyaz Defterleri, Defter nu. I, s. 109-111.

${ }^{38}$ BOA. Bab-1 Ali Eırak Odası Divan-ı Hümayun Kalemi Mühimme Kalemi(BEO ADVN $M K L)$, Dosya 17, Gōmlek 11. 
Bu arada yukarıda belirtilen süre içerisinde ilgililer, gölde vapur işletmeye başlamazlar ise kendilerine verilmiş olan imtiyaz fermanı geçersiz olacaktır. Aynca, söz konusu kişiler, Van Gölü'nde işlettikleri vapurları üç aydan fazla bir süre seferden alıkorlarsa ve devletin sonradan belirleyeceği yerlerde istek tarihinden itibaren en geç bir sene içerisinde vapur seferlerini başlatmazlar ise de imtiyaz fermanı devlet tarafindan fesh edilecektir. Ancak devlet bu fesh işlemini ilgililerden habersiz aniden yapmayacaktur, en az üç ay önceden haber verecektir, bu süre zarfinda istekler yerine getirilmez ise o zaman geçici olarak fesh işlemine geçilecektir(madde 11). Dolayısıyla vapur işletme faaliyetlerini devlet kendisi deruhte edecektir. Bu arada, yine üç aylık bir süre içerisinde imtiyaz sahipleri verdikleri sözü yerine getirmeyecek veya devletin belirlediği yerlerde ve şartlarda işletme faaliyetine yine de geçmeyecek olurlarsa imtiyaz hakkı kati olarak fesh edilecektir(madde 12).

Söz konusu mukavelede imtiyaz sahiplerinin vapur işletebilmek için ihtiyaç duyacakları malzemelerin temini konusunda da onların yararına olan aydınlatıcı tarzda hükümlerin yer aldığı görülmektedir, şöyle ki; her şeyden önce, bu maksada yönelik olarak imtiyaz sahiplerinin yapacak oldukları inşaat için gerekli olup da ülkenin değişik yerlerinden temin edilmesi gereken taş, kereste, demir, maden kömürü, makine ve diğer malzemeler, imtiyaz müddeti boyunca dahili gümrük vergilerinden muaf tutulacaktır. Aynı şekilde Avrupa'dan getirilecek olan alet, edevat, makine ve vapurlar da bir defaya mahsus olmak üzere ve Nafia Nezareti'nin onayından geçirilmek üzere gümrük vergisinden muaf tutulacakur(madde 14). Ayrıca, imtiyaz müddetinin sonuna kadar imtiyaz sahiplerinin vapur işletmeciliğinden elde edecek oldukları gelirlerden de herhangi bir şekilde vergi tarh edilmeyecektir(madde 15).

Bu arada, mukavelede bütün bunlara rağmen devlet, kendi ihtiyaçları için uygun göreceği yerlerde ayrıca vapur işletme hakkını saklı tutmuştur. Ancak burada imtiyaz sahipleriyle rekabet etme düşüncesinin kesinlikle söz konusu olmadığı görülmektedir. Çünkü, mukavelede buna açıklık getirilmiş ve devlet tarafından ticaret maksadına yönelik olarak yolcu ve eşya taşıma işleminin yapılamayacağı belirtilmiştir (madde 16). Diğer yandan, imtiyaz sahiplerinin imtiyaz müddeti boyunca kadimden beri gölde yelken veya kürek ile seyr ve sefer etmekte olan kayıklarm faaliyetlerine her ne şekilde olursa olsun engel çıkarmayacaklarına da değinilmiștir (madde 16). 
Bütün bunlardan başka mukavelede imtiyaz sahiplerinin vapur işletmeye başladıkları andan itibaren devlete ait posta çantalan ve denkleri ile buna benzer eşyalanı bedava taşıyacaklarına dair bir hüküm de vardır (madde 13).

İmtiyaz sahipleri, bu maksada yönelik olarak hazırlayacak oldukları anonim şirketin dahili nizamnamesine dair layihayı devletin kanun ve nizamlarına uygun olarak hazırlayacaklardır ve bunu mukavelenin imza tarihinden itibaren engeç on ay içerisinde onay için ilgili makamlara sunacaklardır(madde 17). Oluşturulacak şirketin merkezi Dersaadet olacak, Van'da da bir şubesi bulunacak ve şirketin kurucu ve mensuplarının tamamı Osmanlı vatandaşı olacakur. Gölde faaliyet gösterecek olan vapurların tamamı da aynı şekilde Osmanlı sancağı taşıyacaklardır(madde 18).

Diğer yandan, imtiyaz sahipleri, imtiyaz süresince hükümetin yapacağı teftiş ve kontroller esnasında ortaya çıkacak masraflarda harcanmak üzere devlete yıllık olarak 120 Osmanlı lirası vereceklerdir(madde 19).

Bütün bunlardan sonra mukavelede, imtiyaz sahipleri ile devlet arasında meydana gelecek her türlü anlaşmazlık konularında Şura-yı Devlet'in, imtiyaz sahipleri ile halk arasında meydana gelecek olan anlaşmazlıklarda ise Nizamiye Mahkemelerinin yetkili olduğu konusunda mutabakata varılmışur (madde 20).

İlgililer, daha sonra yukarıda da zikredildiği gibi mukavelenamenin 17 . maddesine uygun olarak bir şirket tesis olunması için "' hazırlıklarına başlamışlar ve gerek fermanın ve gerekse mukavelenamenin hükümleri doğrultusunda Van Gölü Şirket-i Osmâniyesi adı alunda bir şirket tesis ederek söz konusu şirketin nizamname taslağını hazırlamışlardır "1".

Nizamname, şirketin kuruluş nizamını ve müddetini belirten fasl-ı evvel; sermayesini ve hisse senetlerini belirten fasl-ı sânî; idaresi hakkında hükümleri içeren fasl-ı salis ve Hissederân Umum Meclisi başlığını taşıyan fasl-ı rabi olmak üzere dört bölümden ve otuzyedi maddeden oluşmaktadır. Buna göre, Van Gölü'nde vapur işletmek isteyen şirketin adı yukanda da zikredildiği üzere Van Gölü Şirket-i Osmaniyesi'dir. Yine nizamname hükümlerine göre anonim bir yapıdaki bu şirketin merkezinin Dersaadet'de olması öngörülerek Van'da da .bir şubesinin olması kararlaştırılmıştur. Şirkete ömür ola-

\footnotetext{
${ }^{39}$ BOA, Y.A. Res, Dosya 6, Sıra 18.

${ }^{10}$ BOA, Y.A. Res., Dosya 12, Sıra 20.
} 
rak da, kırk yıllık bir zaman dilimi öngörülmüştür. Başlangıçta 55000 Osmanlı lirası sermayesi olması kararlaşturılan şirketin bu sermayesinin her biri 11 Osmanlı lirası olmak üzere 5000 hisseye taksim edilmesi ve bu miktar hissenin 4500 adedinin piyasaya satışı planlanmışur" $"$.

Önemli gördüğümüz bazı maddelerini belirttiğimiz bu nizamname, imtiyaz sahipleri olan Abraham Kafafyan ve Artin Sarrafyan efendiler tarafindan onay için ilgili birimlere sunulmuştur. İlk olarak Şura-yı Devlet'e havale edilen nizamname, bu kurumun Tanzimat Dairesi tarafından Nafia Nezareti'nin görüşü alınmak üzere buraya havale edilerek incelemeye alınır. Nizamname, Nafia Nezareti tarafından bazı değişikliklere uğratılmış olmalı ki imtiyaz sahipleri, yapılan değişiklikten kendilerine haber edilmediğinden bahisle yapılan değişikliğin kendilerine bildirilmesi için 12 Ocak 1880 tarihinde bir ariza ile başvuruda bulunurlar ${ }^{12}$. Fakat gerekli incelemeler devam ettiği için onların bu isteğine hemen olumlu cevap verilemediği anlaşılmaktadır $^{+3}$. Ancak bu sefer imtiyaz sahipleri, oluşturdukları nizamnamenin tasdikinin gecikmesinden dolayı, zarar ve ziyana uğrayacaklan bahanesi ile uğrayacakları zararın Nafia Nezareti'ne ait olacağı iddiasıyla devlete bir protesto çekerler ${ }^{44}$. Çekilen protesto da incelemeye alınır ve ilgililerin bu itiraz ve iddialarının yersiz olduğu ortaya çıkar. Çünkü, mukavelenin onyedinci maddesine göre imtiyaz sahipleri, mukavelenin imzalandığı tarihten itibaren on ay içerisinde hazırlayacakları nizamname suretini devletin tasdikine sunacaklardır denilmektedir. Halbuki şimdi onlar, mukavelenin imza tarihi olan 13 Ekim 1879 tarihinden daha üç ay bile geçmeden sundukları nizamname layihasının onaylanmasının gecikmesinden dolayı zarara uğrayacaklarından bahsetmektedirler. Nitekim 7 Nisan 1880 tarihinde ilgililerin bu isteklerinin uygun olmadığı yolunda bir kararın kendilerine tebliğ edilmesi yolunda bir görüş ortaya çıkar ${ }^{15}$. Hakikaten Ticaret Nezareti'nde nizamname üzerinde yapılan incelemeler neticesinde söz konusu nizaınnamenin , "...fevaid ve usul-i devlet-i aliyyeye muvafık..." olduğu 16 Mays 1880 tarihli bir arzdan anlaşılmaktadır"ti. (Bkz. ek 3). Yani işlemler normal seyrinde devam etmektedir. Ama imtiyaz sahipleri bu konuda aceleci davranmaktadır. Bu arada Nafia

\footnotetext{
$"$ BOA. Y.A. Res, Dosya 12, Sira 40.

12 BOA, Y.A. Res, Dosya 12, Sira 40.

${ }^{13}$ BOA, Y.A. Res, Dosya 12, Sira 40.

11 BOA, Y.A. Res, Dosya 12, Sira 40.

15 BOA, Y.A. Res, Dosya 12, Sira 40.

"ii BOA, Y.A. Res, Dosva 6, Sura 18.
} 
Nezareti'nden de ilgililerin itirazları ile ilgili olarak görüş alıs verişinde bulunulmuş ve söz konusu kişilerin nizamname ellerine verilmediği için bir türlü işe başlayamamalarından dolayı zarara uğramamalanı için nizamname üzerindeki tedkiklerin bir an önce bitirilerek ellerine verilmesi yolunda görüş ortaya çıkmıştır (31 Mayıs 1880$)^{47}$. Fakat işin ilginç yanı, bundan bir ay soura aynı nezaretin, yaptı̆ı incelemeler neticesinde böyle bir nizamname ile kurulacak şirketin işletmeye başlayamayacağı yolunda görüş bildirmesidir ${ }^{18}$. Dolayısıyla imtiyaz sahiplerinin Van Gölü'nde vapur işletme girișimleri aradan epey bir zaman geçmesine rağmen bir türlü icra alanına konulamamıştur.

Görünen o ki, Artin ve Abraham Efendilerin Van Gölü'nde vapur işletme işine bir türlü başlayamamaları bölge halkını da merakta bırakmış ve heyecanlandırmışur. Çünkü 1 Temmuz 1880 tarihinde Van valisinin muteberan-ı memleket adına İstanbul'a yazmıș olduğu bir arzın bu konu ile ilgili olduğunu görüyoruz Şöyle ki; vali, yazmış olduğu arzda adı geçenlerin Van Gölü'nde vapur işleteceklerinin ve bu konuda bazı faaliyetlerde bulunduklarının duyulduğunu, ancak bu güne kadar bu işe başlanamadığını ve dolayıstyla bu durumun bölge için önemli zararlara sebep olacağından bahsetmekte ve bundan dolayı söz konusu gölde bir an önce vapur işletilmesine başlanmasını istemektedir ${ }^{49}$.

Ama buna rağmen işlemlerin yine bitmediğini ve ilgililere, onay için takdim etmiş oldukları nizamnamenin bir türlü geri verilmemiş olduğunu görüyoruz. Nitekim imtiyaz sahibi kişilerin 31 Temmuz 1880 tarihinde bu nedenle Nafia Nezareti'ne bir arz daha yazmış olduklarını biliyoruz. Söz konusu kişiler, bu arzlar’nda da o zamana kadar nizamnamenin tasdik edilerek kendilerine verilmemış olmasından dolayı işe başlayamadıklarını tekrarlamaktadırlar. Ayrıca, vapur işletme işini yürütebilmek için birtakım iş bağlantularına girmiş olduklarını ama, kendilerine nizamnamenin onaylanarak geri verilmemesi dolayısıyla bu ișe bașlayamadıklarını ve dolayısıla devlet nazarında verdikleri sözü tutmamış konuma düştüklerini belirterek bu durumdan sorumlu olmayacaklarını da arzlarında dile getirmişlerdir. Dolayısıyla bu konuda kendilerine bir cevap verilmesini isterler. Onların bu arzı Nafia na-

\footnotetext{
${ }^{47}$ BOA, Y.A. Res, Dosya 6, Sira 18.

${ }^{48}$ BOA, Y.A. Res, Dosya 6, Sıra 18.

${ }^{10}$ BOA, Y.A. Res, Dosya 12, Sira 40.
} 
zırı tarafından aynı gün sadrazama bildirilir ${ }^{50}$. Söz konusu arz ve buna dayalı olarak Nafia Nezareti'nden gelen tezkere, nizamname taslağı ile birlikte 4 Ağustos 1880 tarihinde de padişaha sunulur ${ }^{51}$. Buna ne cevap verildiğini şimdilik bilemiyoruz. Ancak, başka bir tezkereden anlaşıldığı kadarıyla hükümet, durumu incelemeye almış ve söz konusu nizamnamenin onaylanarak ilgililere geri verilip verilmemesinin Nafia Nezareti'nin yetkisi dahilinde bir iş olduğunu belirtmiştir. Yine aynı arzdan söz konusu gecikmenin Nafia Nezareti'nin tasarrufundan kaynaklandığı anlaşılmaktadır ${ }^{52}$. Nitekim 9 Kasım 1880 tarihinde bu konuları ihtiva eden bir tezkere ile daha karşılaşmaktayız $^{53}$. 18 Ocak 1881 tarihli bir başka tezkerede de söz konusu gecikmenin Nafia Nezareti'nin tasarrufundan kaynaklandığı ve nizamnamenin onaylı suretinin ilgililere verilip verilmemesinin adı geçen nezaretin tasarrufuna ait olduğuna değinilmektedir ${ }^{51}$.

Buradan da anlaşılmaktadır ki, hükümet bu konuyu sürüncemede bırakmıştır ve aradan geçen iki yıla yakın bir süreye rağmen ilgililere Van Gölü'nde faaliyete başlamaları konusunda izin vermemiştir. Hükümet ile imtiyaz sahipleri arasındaki bu anlaşmazlığın veya Nafia Nezareti'nin söz konusu nizamnamenin onaylı suretini ilgililere vermemesinin, daha önce iki taraf arasında imzalanmış olan mukavelenamenin hükümlerinden kaynaklandığı anlaşılmaktadır. Nitekim imtiyaz sahipleri, devletle imzalamış oldukları mukavelenamenin ondokuzuncu maddesi gereğince imtiyaz fermanın verildiği tarihten bir sene geçtikten sonra imtiyaz müddetinin bitimine kadar senelik olarak devlete vermeyi taahhüt ettikleri 120 Osmanlı lirasını o ana kadar Nafia Nezareti veznesine ödememişlerdir ${ }^{55}$. Onlar bu parayı hükümetin yapacak olduğu teftiş ve nezaretlerin masrafının karşılanması için vermeyi kabul etmişlerdir(madde 19). Hal böyle olunca, imtiyaz sahiplerinin devleti sık sık sıkıșturmalarının anlamsız olduğu veya kasıtlı olduğu anlaşılmaktadır.

Fakat bu meselenin devleti oldukça fazla meşgul etmiş olduğunu görüyoruz. Çüıkü 1881 yılının ilk aylarına ait bazı yazışmalar da bu konuya aittir. Nitekim 18 Mart 1881 tarihli bir tezkere ile imtiyaz varakaları Nafia

\footnotetext{
5) BO.A, Yıldız Arşivi Hususi Maruzat Eırakı (Y.A. Hus.), Dosya 165, Sıra 63.

${ }^{51}$ BOA, Y.A. Res, Dosya 165, Sira 63.

22 BOA. Y.A. Res, Dosya 12, Sıra 40.

${ }^{53}$ BOA, Y.A. Res, Dosya 12, Sira 40.

${ }^{51}$ BOA. Y.A. Res, Dosya 12. Sira 40.

55 BOA. Y.A. Res, Dosva 12, Sur 40.
} 
Komisyonuna havale edilir ${ }^{5 i}$ ve yapılan incelemelerden sonra söz konusu komisyonun görüşü rapor haline getirilerek ilgili makamlara ulaştırılır. Komisyonun görüșüne göre, imtiyaz sahipleri Nafia Nezareti'ne vermeleri gereken yıllık bedeli gerçekten o ana kadar vermemişlerdir. Ama onlar bu işi, devletin kendilerine nizamnamelerinin onaylı suretini vermeyi geciktirmesinden dolayı yapmışlardır. Böyle olunca, bir an önce söz konusu kişilere nizamnamenin onaylı suretinin verilmesi gerektiği şeklinde bir görüş ortaya çıkar $^{57}$. Bundan birkaç gün sonra da söz konusu komisyonun görüşü padişaha bildirilir ${ }^{\text {is }}$. Ama aynı senenin ağustos ayına kadar bu konuda olumlu bir iradenin çıkmamış olduğunu görüyoruz. Çünkü 16 ve 25 Ağustos 1881 tarihli iki adet tezkere ile bu konuda yine irade-i seniyyenin istenilmiş olduğunu görüyoruz ${ }^{59}$. Kaynaklardan anlaşıldığı kadarıyla devletin, ilgililere vermiş olduğu imtiyazı yürürlüğe koydurmamasının sebebinin aslında "..ahval-i icabat-ı mahalliye..."den kaynaklandığı ortadadır. Bundan dolayı şirketin yukarıda belirtilen nizamnamesi tasdik edilmemiş ve ilgililere onaylı sureti bir türlü verilmemiştir ${ }^{6 i 0}$. Böyle olunca, așağıda da değinileceği üzere imtiyaz sahipleriyle devlet arasında bu sefer başka bir problem gündeme gelecektir.

Devletin bu işi yani Van Gölü'nde vapur işletme işini daha uzun süre sürüncemede bırakuğı görülmektedir. Çünkü 1888 yılına ait bir Meclis-i Vükela mazbatasından bunun böyle olduğu anlaşılmaktadır ${ }^{\text {iil }}$. Şöyle ki, belirtilen tarihe gelindiğinde bu sefer de Van valiliğinden hükümet merkezine bu vilayet dahilinde bir şose yolun inşası ile Van Gölü'nde vapurlar yapılması yolunda istek gelmiştir. Bu isteğin Meclis-i Vükela tarafından incelenmesine dair kaleme alınan mazbatada bu hususa değinilerek, daha önceki yıllarda söz konusu gölde vapur işletme faaliyetlerinin evveliyatına atıfta bulunularak, bugüne kadar yani 1888 yılı mayıs ayına kadar bu işin fiiliyata geçirilemediğine, ama, imtiyaz hükmünün hâlâ ilgililer lehine geçerli olduğuna değinilmektedir ${ }^{\text {i2 }}$. Ama bu arada ilginç bir gelişme de göze çarpmaktadır ki o da, ilgililere verilen imtiyaz fermanında devletin kendi ihtiyaçlarını karșılamak için Van Gölü'nde vapur işletme hakkının saklı olduğundan hareketle,

\footnotetext{
5*i BOA, Y.A. Res, Dosya 12, Sira 40.

${ }^{57}$ BOA, Y.A. Res. Dosya 12, Sira 40.

${ }^{58}$ BOA, Y.A. Res, Dosya 12, Sıra 40. Bu telhisin tarihi 16 Mart 1881 'dir.

"10 BOA, Y.A. Res, Dosya 12, Sira 40.

(6) BOA, Y.A. Res, Dosya 100, Sira 26.

${ }^{151}$ BOA, Meclis-i Vükela Mazbatalan (M.V.), Defter nu. 32. Belge nu. 33-1.

${ }^{162}$ BOA, M.V., Defter nu 32, Belge nu. 33-1.
} 
bu gölde yolcu ve eşya taşımak için hükümetçe iki tane vapurun işletilmesinin gündeme gelmiş olmasıdır ${ }^{13}$.

\section{b- İmtiyaz Sahiplerinin Hak Arama Mücadeleleri:}

Bütün bu gelişmelerden sonra hükümetin bu konuda nihai kararı vererek söz konusu gölde devlet tarafından gemi işletilmesi için teşebbüslere başlamış olduğunu görüyoruz. Ancak bütün bu gelişmeler, az önce yukarıda işaret edildiği üzere beraberinde bir bașka problemi gündeme getirivordu ki bu da, devletin vermiş olduğu söz gereğince imtiyaz sahibi kişilerin ișe başlamak durumunda olmaları ve bunun için gerekli ön hazırlıklar çerçevesinde birtakım yatırımlara girişmeleri ve şimdi bu yatırımların aul durumda kalması idi. Yani imtiyazı elde eden Artin ve Abraham Efendilerin ortada kalmaları ve yaptıklarını iddia ettikleri yatırımlara karşılık olarak devletten alacaklı duruma düșmeleri idi. Bu problemin de epeyce bir zaman devam ederek devleti meşgul etmiş olduğunu görüyoruz. Nitekim 27 Kasım 1899 tarihinde söz konusu kişilerden hayatta olan Artin Efendi, tarafindan bu konuda bir arzın vaki olduğunu görüyoruz. Bu arzdan anlaşıldığı kadarıyla ilgililer, bu iş için harcamış oldukları 95000 kuruşun kendilerine iadesi için daha önceden başvuruda bulunmuşlar fakat, kendilerine buna karşılık olarak 40000 kuruşluk bir ödeme teklif edilmiştir. Artin Efendi, şimdi söz konusu miktarın yaptukları ması afları karşılamayacağını belirterek 95000 kuruşun aynısıyla kendilerine geri ödenmesini istemiştiritit. (Bkz., ek 4).

$\mathrm{Bu}$ istek üzerine durum hükümet tarafından hemen incelemeye alınır ve 26 Şubat 1899 tarihiyle Meclis-i Nafia ve Ticaret'den kaleme alınan tezkerede, ilgilinin isteğinin haklı görüldüğü ve hatta imtiyaz sahiplerinin zamanında devlete verdikleri 500 liralık kefaletin bile geri verilmemiş olmasından bahisle, imtiyaz hükümlerinin hâlâ yürürlükte olduğuna değinilmiştir. Dolayısıyla, ilgililere bir miktar paranın geri verilmesinin, ama, bunun karşılığında da imtiyaz fermanımın geri alınmasının uygun olacağına işaret edilmiştir. Bu düşünceden hareketle söz konusu meclisin Artin Efendi'ye 40000 kuruş teklif etmiş olduğu, ancak ilgilinin bu miktarı kabul etmediği de aynı tezkerede göze çarpmaktadır ${ }^{t i 5}$. Bu konuda kaleme alınan tezkerede belirtilen görüşler silsile yolu ile padişaha kadar iletilir. Hükümetin, Artin Efendi

\footnotetext{
${ }^{63}$ BOA, M.V., Defter nu. 32, Belge nu. 33-1.

${ }^{61}$ BOA, Y.A. Res, Dosya 100, Sira 26.

is BOA. Y.A. Res, Dosya 100, Sira 26.
} 
ile geri verilecek para miktarı konusunda sıkı pazarlıklar yürütmüş olduğu ve bu işi en üst düzeyde ele almış olduğu kaynaklardan anlaşılmaktadır. Çünkü 28 Mayıs 1899 tarihi itibariyle Dahiliye, Bahriye, Harbiye, Adliye, Maliye, Adliye, Nafia ve Ticaret ile Evkaf nazırlarından ve Serasker, Şura-yı Devlet Reisi, Tophane Müşiri ve Sadaret Müsteşarından oluşan Meclis-i Mahsusun kaleme almış olduğu bir başka tezkere bize bu durumu açıkça göstermekte$\operatorname{dir}^{66}$. (Bkz. ek 5). Ki, bu tezkereden Artin Efendi'nin 50000 kuruşluk bir tazminat karşılığında rızasının alınmış olduğunu da anlıyoruz. Böylece devlet, Van Gölü'nde kendisinin vapur işletme girişimlerinin karşısındaki en büyük engeli de aşmış bulunuyordu. Çünkü varılan anlaşma gereğince Artin Efendi ve ortağına verilen imtiyaz fermanının iptal olunacağı ve bu işten hükümetin ibra olunacağı konusunda iki taraf da görüş birliği sağlamıștur.

Fakat yine bilemediğimiz bir sebepten dolayı bu sefer ilgiliye verilen bu sözün de devlet tarafindan yerine getirilemediğini görüyoruz. Çünkü 19 Kasım 1901 tarihinde Artin Efendi, Nafia ve Ticaret Nezareti'ne bir daha baş vuruda bulunmuş ve bu sefer de kendisine vadedilen 50000 kuruşun iki seneden beri ödenmediğini belirterek ödemenin yapılmasını devletten istemiștiri ${ }^{i 7}$.

\section{2- Osmanlı Devleti'nin Van Gölü'nde Vapur İşletme Teşebbüsleri:}

Devletin, 1888 yılına kadar bir türlü gerçekleştirilemeyen Van Gölü'nde özel girişimciler tarafından vapur işletme teșebbüsünün ardından, meseleye kendisinin el atmış olduğunu ve az önce de belirtildiği üzere adı geçen gölde en azından iki tane vapurun işletmeye alınması için faaliyetlere başlamış olduğunu görüyoruz. Bu gölde devlet adına vapur işletilmesi görüşünün ilk sahibinin 1897 yılında Anadolu Islahat Umum Müfettişi sıfatı ile bölgede incelemelerde bulunan Yaver Müşir Şakir Paşa olduğunu biliyoruz. O, bu konudaki fikrini Van vilayetinde idari ve diğer bazı hususlarda teftiş faaliyetlerinde bulunduktan sonra Bab-1 Aliye 2 Nisan 1897 tarihinde sunmuş olduğu layihasında dile getirmiştir ${ }^{i 8}$. Şakir Paşa, sözkonusu layihasında bu konudaki gerekçelerini şu şekilde sıralar: Her şeyden önce Van Gölü'nde vapur ișletilmeye bașlanması bu vilayet ile Bitlis vilayetinde ziraat ve ticaretin geliş-

\footnotetext{
ini BOA, Y.A. Res, Dosya 100, Sira 26.

${ }^{67}$ BOA, Y.A. Res, Dosya 11, Sira 71.

${ }^{68}$ BOA. (Yildız Esas Evraki) Y.E., E., 24-XII.
} 
mesine katkı sağlayacakur ${ }^{(3)}$. Ayrıca, Bargiri'de çıkarılacak olan petrol gölde çalışturılacak olan vapurlar sayesinde istenilen yere kolayca nakledilebilecektir. Sonra, Van, Bitlis ve Erzurum vilayetlerinde asayiş ve güvenliğin sağlanması ve devam ettirilmesinde de gölde çalışurılacak vapurlardan istifade edilebilecektir. Aynı şekilde Van, Bitlis, Erzurum, Erciş, Adilcevaz, Ahlat ve Tatvan'da ticaretin geliştirilmesinde de vapurlarm katkısı olacaktır. Cü̈nkü gölde işletilecek olan vapurlar sayesinde İran ile Trabzon arasındaki kervan yolu otuzalu saat kısalulacakur. Böylece Iran'dan Trabzon'a giden kervanlar eskisi gibi Bakü üzerinden değil de artık, doğrudan Van- Erzurum güzergahından geçeceklerdir ${ }^{70}$. Bu da tabii olarak bu güzergah üzerinde bulunan şehirlerin ekonomik kalkınmasına olumlu yönde katkı sağlamış olacaktır.

Şakir Paşa'nın bu layihası hemen işleme alınır ve Van Gölü'nde İdare-i Mahsusa'ya ait olmak üzere ve ihtiyaç duyulacak miktarda vapur ve şilep imal edebilecek ufak çaplı bir tersanenin 1897 yılımın bahar aylarına kadar yetiştirilmesi ile bu konularda Bahriye dairesine yardımcı olmak üzere durumun müzakere edilmesi konusunda bir irade-i seniyye yaynlanır ${ }^{71}$. Bunun üzerine durum Bahriye Nezareti tarafundan vükela heyetinden oluşan bir meclis-i mahsusa incelettirilir ve 18 Ekim 1896 tarihli bir mazbata hazırlanır ${ }^{72}$. Gelen mazbatada, burada yapılacak olan vapur ve dubalar ile tersane ve iskeleler için inşaat masrafı olarak 16030 liraya ihtiyaç duyulacağı ve bunun 7000 lirasının mahallinden, geri kalanının da istikraz yolu ile sağlanabileceğine işaret edilir. Bu mazbataya ek olarak Tersane-i Amire İmalat Dairesinden de bir keşif defteri hazırlaturılır ${ }^{73}$. (Bkz., ek 6). Burada sözünü ettiğimiz keșif defteri Van Gölü'nde yapılacak olan vapurların teknik özellikleri hakkında bize bilgi vermesi açısından oldukça önemli görünmektedir.

\section{a- Vapur Ve Şileplerin Teknik Özellikleri:}

Yukarıda sözünü ettiğimiz keşif defterine dayanarak inşası düşünülen iki adet vapurun ve üç adet şilebin teknik özellikleri hakkında şu bilgileri verebiliriz: Her şeyden önce vapurların araba vapuru tarzında ve yandan çarklı, cer görünümlü olarak düșünülmüss olduğunu görüyoruz. Vapurlar, boyut olarak ise yüzer metre uzunlığunda ve su seviyesinde görünen genişlikleri

\footnotetext{
${ }^{63}$ BOA, Y.E. E., 24-XIII.

${ }^{70}$ BOA, Y.E.E., 31/76, 47; 76/81.

${ }^{71}$ BOA, Irade Bahrive (Ir: Bahr.) 1314, Sira 98, Genel 1357.

72 BOA, ir. Bahr., 1314, Sıra 98, Genel 1357.

${ }^{73}$ BOA, Ir. Bahr., 1314, Sira 98, Genel 1357.
} 
onyedişer kadem ${ }^{71}$ ve güvertelerinin genişliği de yirmibeşer kadem olarak düşünülmüștür. Vapurlar yükseklik olarak ise su seviyesinden üçbuçuk nihayet en fazla dört kadem olarak tasarlanmıştır. Ahşap olarak imali tasarlanan vapurların saatteki sürati ise dokuz mildir. Şileplerin de vapurlar ile aynı büyüklükte olmalarının tasarlanmış olduğunu görüyoruz.

\section{b- Vapurlann İşletmeye Konulması:}

Söz konusu mazbata, az önce işaret edilen keşif defteri ile birlikte 27 Ekim 1896 tarihinde bir tezkere halinde padişaha sunulur ${ }^{75}$. Ardından da Van Gölü'nde küçük çaplı vapurların Tersane-i Amire tarafından inşa edilmesi ve sözü edilen gölde İdare-i Mahsusa'ya bağlı olarak bir de Vapur İdaresi kurulması konusunda irade çıkar. Bu irade ile Binbaşı Reşit Bey isminde birisi vapur idaresinin kurulması konusunda görevlendirilir ${ }^{76}$.

Fakat Abraham ve Artin Efendilere imtiyaz verilip de bir türlü maksadın elde edilememesine benzer bir sürecin burada da yaşanmış olduğu dikkat çekmektedir. Çünkü 1904 yllında bile hâlâ devletin bu işle uğraşmakta olduğunu görüyoruz ${ }^{77}$. Sözü edilen tarihte Sadaret Dairesinden kaleme alınan bu tezkerede iki vapur için lazım olan meblağın nasıl temin edilip harcanacağı hakkında açıklamalar yer almaktadır. Öyle ki aradan üç yıl geçmesine rağmen meselenin yine de halledilememiş olduğu anlașılmaktadır. Nitekim 1907 yilında Harbiye Nezaretinden kaleme alınan bir tezkere bize bu konuda bilgi vermektedir ${ }^{78}$. Şöyle ki, devlet, Van Gölü'nde işletilmesi gündemde olan vapurlan bu sefer satun alma yolu ile temin etme yolunu tercih etmiş görünüyor. Ama, tezkerede bu konudaki emrin daha öncelerden verilmiş olduğundan bahisle, hâlâ bir şeyin yapılmamış olduğuna değinilmektedir. Öyle ki, bu gecikmenin nereden kaynaklandığının araşturılması konusunda daha önce bir irade-i seniyye bile çıkmıştur. Ancak hemen belirtelim ki bu gecikme hususunda Harbiye Nazırının aymı tezkerede bilgi verdiğini de

${ }^{74}$ Kadem: Ayak, adım, tahmini $37.5 \mathrm{~cm}$.

75 BOA, Ir. Bahr., 1314, Sira 98, Genel 1357.

$7{ }^{76}$ Ali Karaca, Anadolu Islahau ve Ahmet Şakir Paşa(1838-1899), İstanbul, 1993, s. 149. Burada Vital Cuinet'e dayanılarak, bölgede yŭrütūlen faaliyetlerin neticesinde Van Gölü'nde oniki ton ağırlık taşıyan ve dōrder kişi tarafından idare edilebilen 87 yelkenlinin işletmeye konulduğundan bahsedilmektedir. Bkz, aym çalışma s, 149. Bizce bu bilgi, devlet tarafindan uzun süredir yürütülen gayretlerin maksadı ile uyuşmamaktadır.

${ }^{77}$ BOA, Y.A. Res., Dosya 127, Sira 76.

${ }^{78}$ BOA, Yildız Arşisi Mütenevvi Maruzat Evrakı (Y. MTV), Dosya 298, Gōmlek, 112, Sıra 3431 . 
görüyoruz. Buna göre gölde vapur işletme işinin tehirine sebep olarak; yapt1rulacak veya satın alınacak vapurların mahalli ihtiyaçlara uygunluğunun ve vapurlarda kullanılacak yakıtın cinsinin tespiti ve bu yakıtun nasıl temin edileceği hususlarının karara bağlanmasının uzun zaman alması gösterilmiştir. Aynı şekilde tezkerede, gölde yapturılacak iskelelerin yerlerinin tayininin de uzun zaman aldığına değinilerek, bu konularda kararın geç verilmesi de bu hususta sebep olarak gösterilmiştir. Anlaşıldığı kadarıyla Harbiye Nezareti bu meseleyi, kendisi araşurıp çözümleyeceği yerde, daha önceki girişimlerin yürütücüsü olarak bildiğimiz Bahriye Nezareti ile bu konuda uzun zaman alan görüşmeler yaparak halletmeyi düşünmüş̧ür. Ardından da Bahriye nazırı bu görüşmeleri işin gecikmesine bahane olarak göstermiştir. Bütün bunlardan sonra Harbiye Nazırı, gölde işletmeye konacak olan iki vapurun satın alınması konusunda "...muteber ve mutemed..." fabrikalara müracaat edileceğinden bahisle, verilecek tekliflerden hazine menfaatine en uygun olanlar1nın tercih edilerek "...müsaade-i seniyye..." ile bu gemilerin satun alınacağından bahsetmektedir.

\section{Sonuç:}

Kaynaklardan anlaşıldığı kadarıyla daha Orta Asya'dan beri denizciliğe aşina olan bir milletin mensubu olarak Anadolu Türklüğü, bu coğrafyada XVI.yüzyılın sonlarına kadar denizcilik alanında etkin görünüyor. Ancak, söz konusu dönemden itibaren Osmanlı'nın diğer kurumlarındaki dejenerasyona paralel olarak bu alanda da güçsüzlük ve zaafiyet emareleri baş göstermiştir.

Belki de bunun tabii sonuçlarından biri olarak bakıyoruz ki, Osmanlı iç sularında taşımacılık faaliyetleri ihmal edilmiş veya hiç gündeme gelmemiş gibi görünüyor. Ne zaman ki Avrupa emperyalizminin ekonomik alandaki yayılmacılık faaliyetleri Osmanlıya da el atu, o zaman resmi anlamda bu işin önemi kavranmaya başlanmış ve bu alanda çeşitli yerlerde gerek akarsularda ve gerekse göllerde olmak üzere taşımacilık işine girişilmeye başlanmışur.

Bu tür yerlerden birinin de Van Gölü olduğunu görüyoruz. Ama ilginçtir ki, bu gölde de taşımacılık sektörüne ilk olarak el atan devlet kurumları veya Türk unsuru değil gayr-i müslim tebadır. Bu anlamda iki kişinin başlatuğı faaliyetlere başlangıçta yeşil ışık yakılmış iken ve kaynaklardan anladığımız kadarıyla bu kişiler de bu işe bir miktar yaurım yapmış iken devlet, daha sonradan mahalli mazeretleri öne sürerek bu işi sürüncemede bırakmışur. 
Sonradan, bölgenin kalkınmasına, ticaretin gelişmesine ve asayişin sağlanmasına katkıda bulunur gibi düşüncelerle devletin bu işe bizzat kendisinin teşebbüs etmiş olduğunu görüyoruz. Ama ne gariptir ki devlet, bu sefer kendi yapacak olduğu iște de alabildiğine ihmal sergilemiş ve uzun süre bu işi sürüncemede bırakmıştır. Üstelik daha önce söz konusu gölde vapur işletme hak ve imtiyazını vermiş olduğu kişilerin tazminat isteklerini karşılamak gibi bir zorunluluk ile de karşı karşıya olmasına rağmen. Ama sonuçta XX. yüzyılın ilk başlarında gerekli yerlerden gemi satun alınmasına karar vererek, devlet, bu konudaki nihai çözümünü ortaya koymuş görünüyor.

Bu arada olayların gelişimi bize Osmanlı'nın denizcilik kültürü açısından Avrupa'dan ne kadar gerilerde olduğunu ve ayrıca, bu alandaki uyanışın da Avrupalı yaurımcıların Osmanlı sularına girmesi sayesinde gerçekleşmiş olduğunu göstermektedir. 


\section{4 \\ Dis}

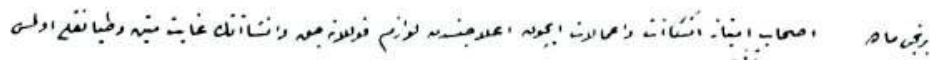

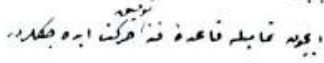

.

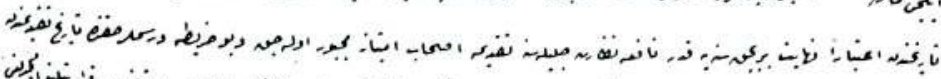
:

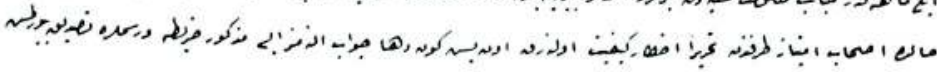

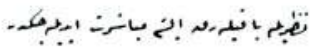

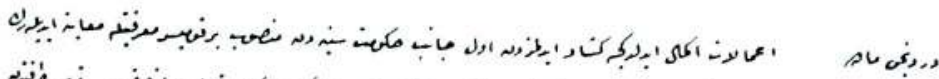

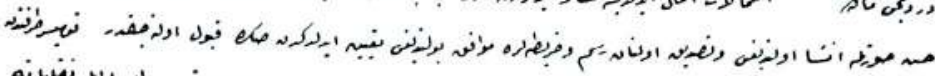

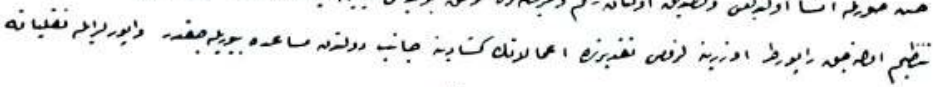

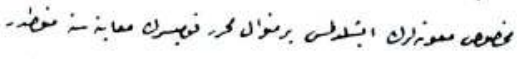

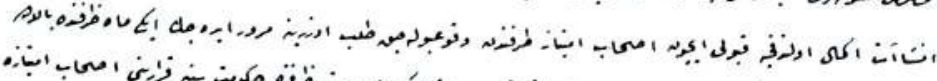

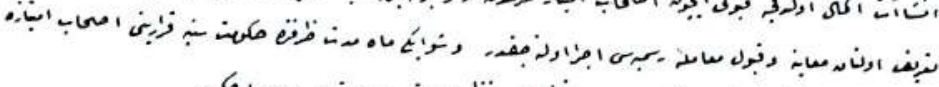
ن.

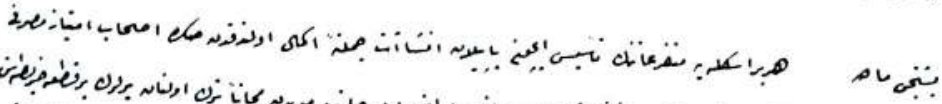

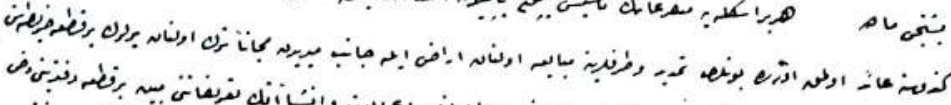

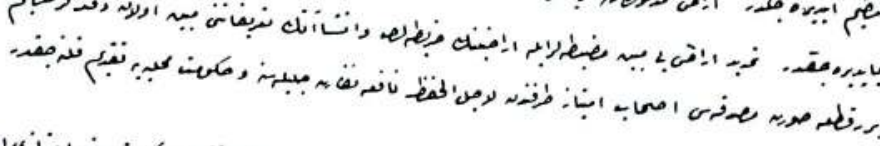

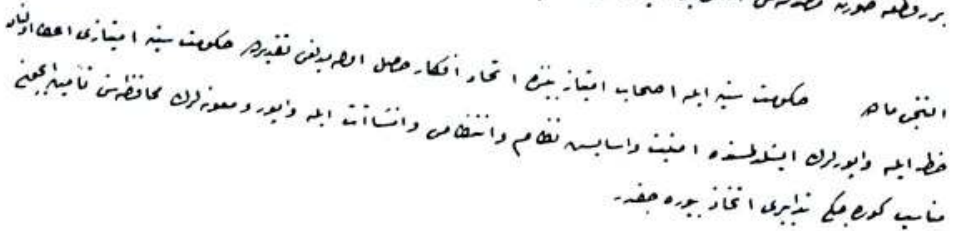

Ek 1: Van Gölü'nde vapur işletecek şirketin teşkili ile ilgili şartnamenin başlangıç maddeleri.

BOA, BEO, ADVN MKL, Dosya 17, Gömlek 11. 
Fahrettin Tizlak

مغاولام

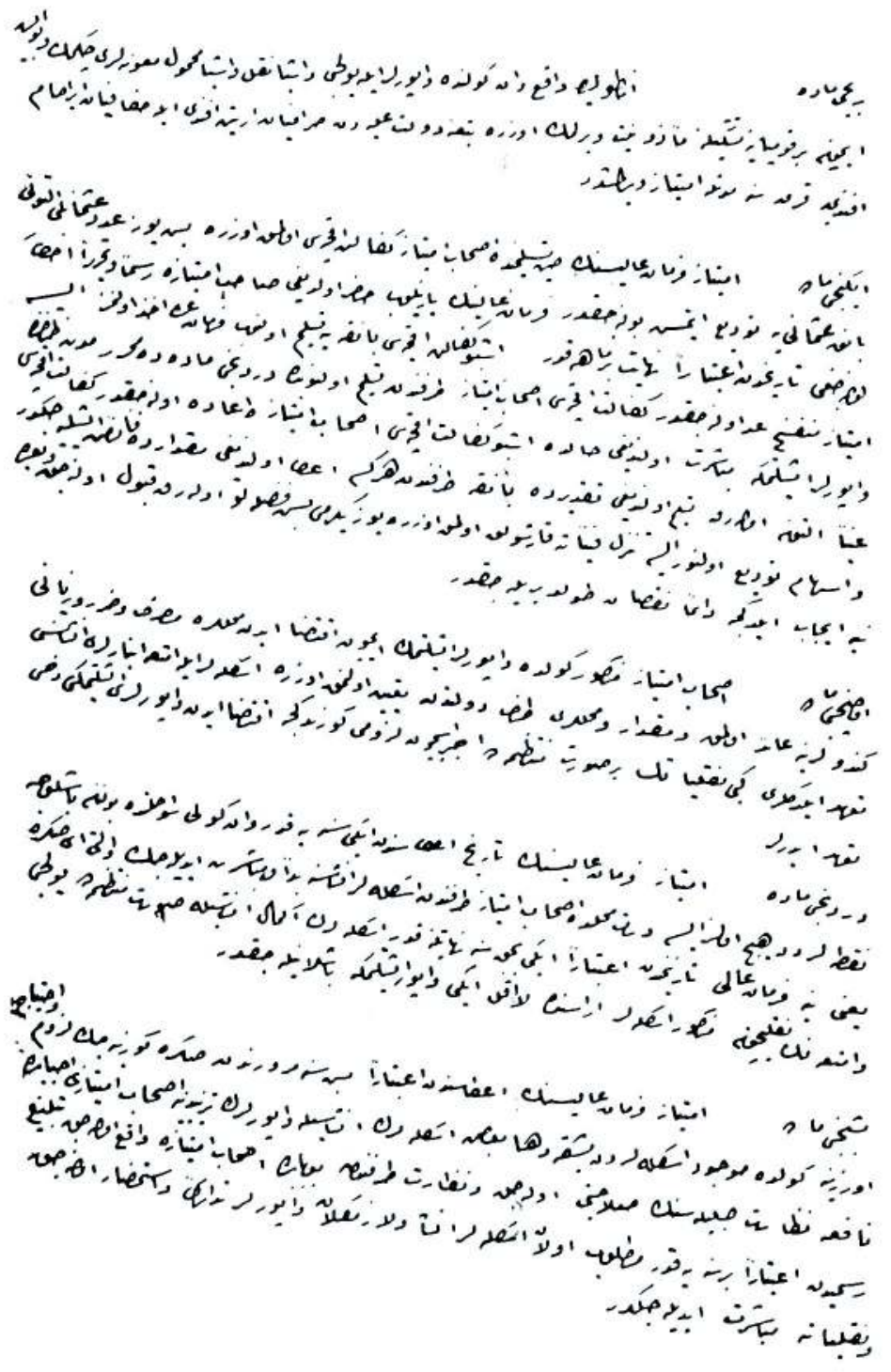

Ek 2: Van Gölü'nde vapur işletecek şirketin teşkili ile ilgili mukavelenamenin başlangıç maddeleri.

BOA, BEO, ADVN MKL, Dosya 17, Gömlek 11. 
Fahrettin Tizlak

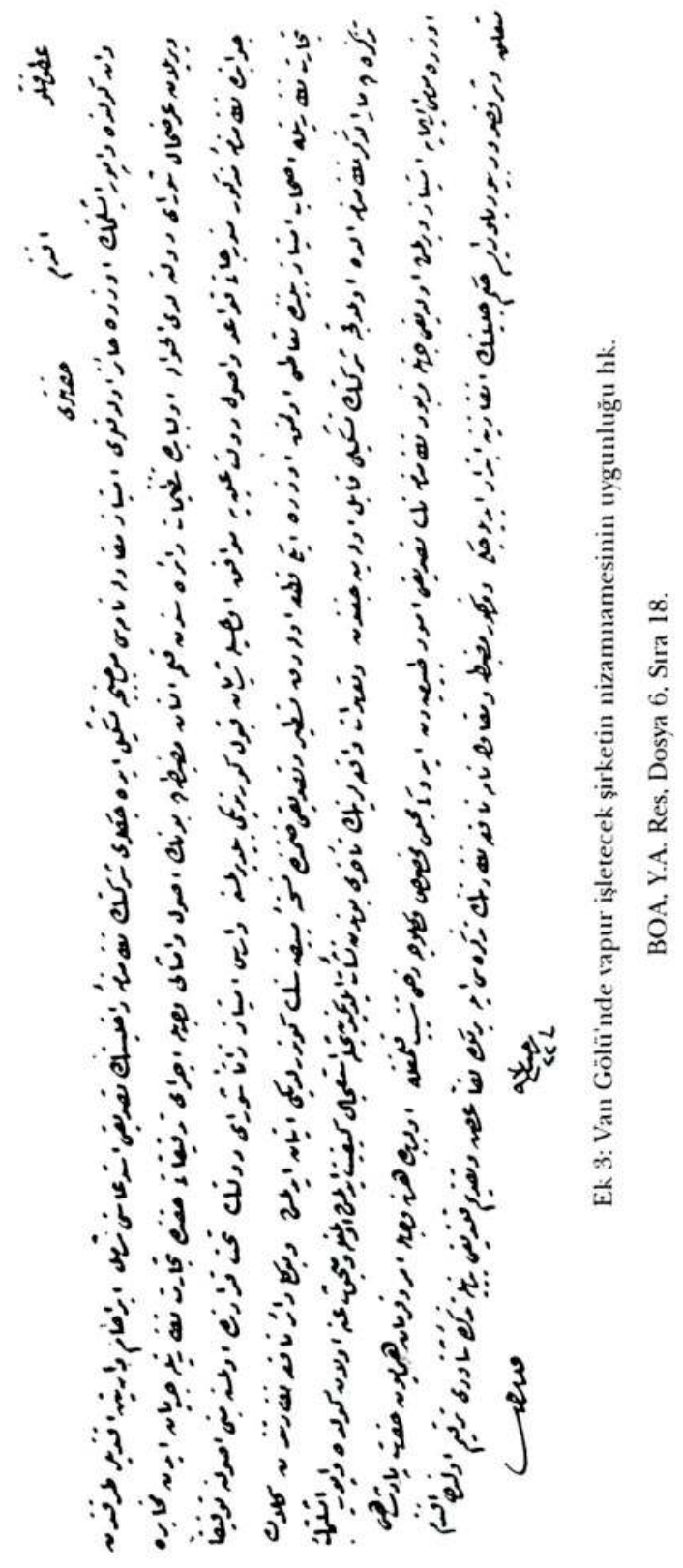




\section{Fahrettin Tizlak}

viduteres

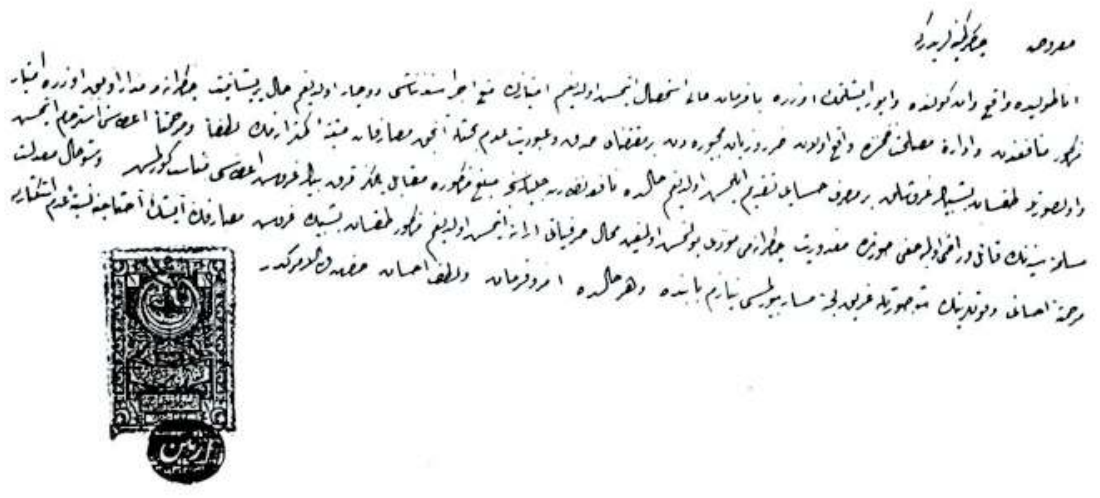

Ek 4: Artin Efendi'nin arzhali.

BOA, Y.A. Res, Dosya 100, Stra 26. 


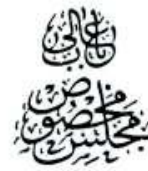

14.

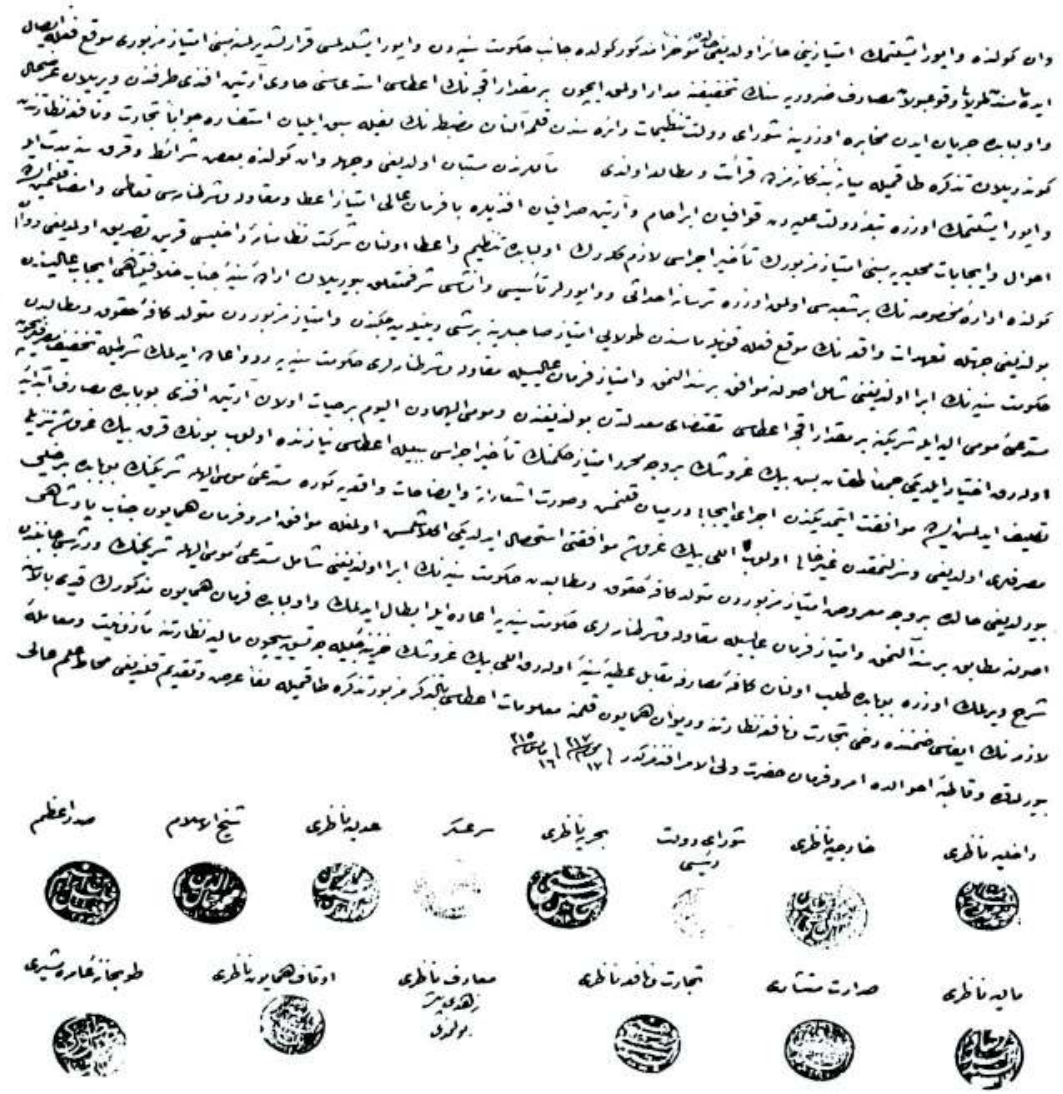

Ek 5: Artin Efendi'nin isteği hakkında meclis-i mahsusun kaleme aldığı tezkere.

BOA, Y.A. Res, Dosya 100, Sira 26. 


\section{Fahrettin Tizlak}
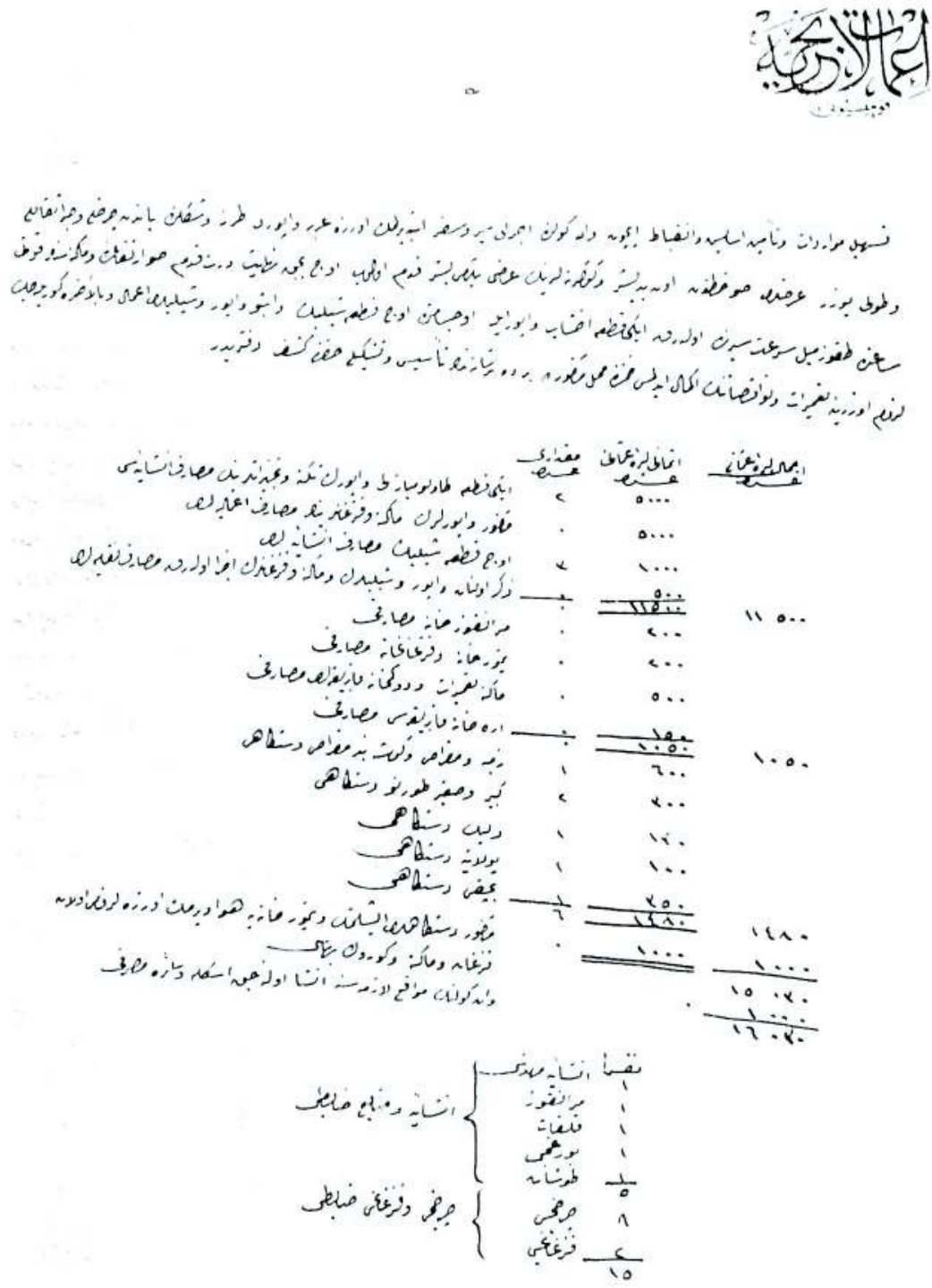

Ek 6: İare-i Mahsusa'ya ait vapur ve şilep imal edecek bir tersanenin inşası ile ilgili keşif defteri.

BOA, Ir., 1341, Sıra 98, Genel 1357. 